\title{
Enzyme Fuel Cell for Cellulolytic Sugar Conversion Employing FAD Glucose Dehydrogenase and Carbon Cloth Electrode Based on Direct Electron Transfer Principle
}

\author{
Desriani $^{\mathrm{a}}$, Takuya Hanashi ${ }^{\mathrm{a}}$, Tomohiko Yamazaki ${ }^{\mathrm{b}}$, Wakako Tsugawa ${ }^{\mathrm{a}}$ and Koji Sode ${ }^{\mathrm{a}, *}$
}

${ }^{a}$ Department of Biotechnology, Graduate School of Engineering, Tokyo University of Agriculture and Technology, 2-24-16 Naka-cho, Koganei, Tokyo 184-8588, Japan

${ }^{b}$ National Institute for Materials Sciences (NIMS), Biomaterials Center (BMC), Advanced Medical Materials Group, International Center for Materials Nanoarchitectonics (MANA), Medical Materials Group, 1-1 Namiki Tsukuba Ibaraki, 305-0044, Japan

\begin{abstract}
An enzyme fuel cell employing a carbon cloth electrode and bacterial FAD dependent glucose dehydrogenase (FADGDH) based on the direct electron transfer principle was constructed, and its scalability and cellulolytic sugar conversion were investigated. FADGDH was immobilized on the carbon cloth electrode together with carbon paste to form a multi-module type enzyme fuel cell by combining platinum-supported carbon immobilized carbon cloth as the cathode. The enzyme fuel cell was stable for more than 7 days of continuous operation. The $3 \times 3$ module $\left(18 \mathrm{~cm}^{2}\right)$ enzyme fuel cell generated $68 \mu \mathrm{W}\left(3.8 \mu \mathrm{W} / \mathrm{cm}^{2}\right)$ using glucose as the substrate, which was almost 9 times that of a single-module enzyme fuel cell. Thanks to the substrate specificity of bacterial FADGDH, cellulolytic sugars were revealed to be a good substrate for the enzyme fuel cell with cellobiose $\left(9.3 \mu \mathrm{W} / \mathrm{cm}^{2}\right)$, cellotriose $\left(9.2 \mu \mathrm{W} / \mathrm{cm}^{2}\right)$, or cellotetraose $\left(6.3 \mu \mathrm{W} / \mathrm{cm}^{2}\right)$. These results demonstrated that together with the feasibility of using carbon cloth as the electrode material, FADGDH as the anode catalyst will become the norm in electrochemical biomass applications in the future.
\end{abstract}

Keywords: FADGDH, Carbon cloth electrode, Direct electron transfer, Biofuel cells.

\section{INTRODUCTION}

Biofuel cells, in which either enzymes or whole cell organisms are used as the catalyst, have attracted much attention for generating electric power directly from sustainable fuel substrates such as glucose and ethanol. Numerous enzyme fuel cells employing glucose oxidizing enzyme have been reported [1]. However, conventionally utilized oxidases and dehydrogenases are not able to carry out the direct electron transfer with electrode materials, as the catalytic center, in which the redox center and co-factor exists, is usually buried deeply in the enzyme protein molecule and is not exposed to the surface. Early direct electron transfer studies using these enzyme molecules were achieved by the chemical modification enzyme molecules by redox dyes and by employing self assemble monolayer (SAM) in order to control the orientation and distance between electrode and enzyme, consequently facilitate the direct electron transfer. Recently several researchers reported on the use of carbon nano tube as the electrode material, thereby achieved the direct electron transfer using glucose oxidase [2]. Unfortunately, employment of chemical modification and/or expensive nano materials obliges the complicated procedures to fabricate the enzyme fuel cell aiming the biomass utilization.

\footnotetext{
*Address correspondence to this author at the Department of Biotechnology, Graduate School of Engineering, Tokyo University of Agriculture and Technology, 2-24-16 Naka-cho, Koganei, Tokyo 184-8588, Japan;

Tel/Fax: +81-42-388-7027; E-mail: sode@cc.tuat.ac.jp
}

Recently, cellobiose dehydrogenases (CDHs; EC 1.1.99.18) have been extensively utilized as the enzymes for bioanodes. CDHs are extracellular, glycosylated proteins produced by several fungi such as white rot fungi [3]. CDHs have a unique enzyme structure composed of two distinct domains, the C-terminal flavin domain, which is the catalytic domain, and the N-terminal cytochrome-b type heme domain, which acts as the electron transfer domain between the flavin-containing catalytic domain and external electron acceptors [4]. The presence of the heme domain enables CDHs to transfer electrons directly with the electrode. Together with the inherent substrate specificity of $\mathrm{CDHs}$ that can oxidize cellobiose (Glc- $\beta$-1,4-Glc) and other $\beta$-1,4-linked di- or oligosaccharides at $\mathrm{C}-1$ to the corresponding lactones, $\mathrm{CDHs}$ are currently an attractive anode catalyst for enzyme fuel cells aiming for electrochemical utilization of biomass $[5,6]$. However, CDHs cannot be functionally expressed by the prokaryotic recombinant host [7]. In addition, CDHs so far reported scarcely react with glucose or other monosaccharides [4]. In spite of their superior properties versus GOD, further improvements at the molecular level are still required before CDHs can be used in practical biomass utilization.

We have recently reported a fuel cell type glucose sensor using a FAD dependent glucose dehydrogenase (FADGDH) as an anode enzyme $[8,9]$. FADGDH is originally a membrane bound, thermostable, periplasmic enzyme purified from Burkholderia cepacia, but we prepared the enzyme 
recombinantly using Escherichia coli as the host [10-16]. This FADGDH consists of three subunits: a catalytic subunit containing FAD, an electron transfer subunit harboring heme $\mathrm{c}$, and a small subunit that acts as a chaperone-like component $[14,15]$. FADGDH showed direct electron transfer from the catalytic center of the enzyme to the electrode, thanks to the presence of electron transfer heme containing the cytochrome c subunit, therefore fuel cells employing FADGDH as an anodic biocatalyst do not need their own compartment. We previously reported an enzyme fuel cell type glucose sensor, and demonstrated its potential for a direct electron transfer type enzyme fuel cell $[8,9]$. We also reported on the carbon cloth electrode based enzyme fuel cell using FADGDH for the construction of a unique biocapacitor biosensor [17]. However, the carbon cloth enzyme fuel cell has not yet been characterized, including its scalability and stability. In addition, as FADGDH shows wide substrate specificity, it is expected to be useful for cellulolytic biomass electrochemical conversion.

In this paper, we used recombinantly prepared FADGDH to construct a carbon cloth based direct electron transfer type enzyme fuel cell, and investigated its feasibility in terms of operational stability and scaling up. We also attempted to use several cellulolytic sugars as the substrate of the thus constructed enzyme fuel cell to investigate its potential for electrochemical utilization of biomass.

\section{MATERIALS AND METHODOLOGY}

\subsection{Materials}

Recombinant FADGDH complex was prepared using the expression vector pTrc99A, containing the structural gene for GDH complex (pTrc $\gamma \alpha \beta)$, and pEC86 containing the structural gene for ccm (pEC86), and was transferred into an E. coli strain BL21 (DE3) and cultivated as described previously [13]. Carbon cloth, SYCC18-00000-00, was provided by Toho Tenax (Tokyo, Japan). Platinum-supported carbon $(\mathrm{Pt} / \mathrm{C})$, TEC10E50E, (Pt wt\% = 50) was purchased from Tanaka Kikinzoku Kogyo (Tokyo, Japan). Glutaraldehyde solution (25\%; w/v) was purchased from Wako Pure Chemicals (Osaka, Japan). Carbon graphite, Nafion perfluorinated resin solution and poly(dimethyl-siloxane) (PDMS) were purchased from Sigma-Aldrich (St. Louis, MO). Pt mesh electrode was purchased from BSA Inc. (West Lafayette, USA). All other chemicals were of reagent grade.

\subsection{Enzyme Fuel Cell Construction and Operation for Multi-Module Enzyme Fuel Cell}

The carbon inks and Pt/C ink were made as follows: 100 mg of carbon graphite or $\mathrm{Pt} / \mathrm{C}$ was mixed with $400 \mu \mathrm{L}$ of ultrapure water and $1.08 \mathrm{~mL}$ of $5 \%(\mathrm{w} / \mathrm{v})$ Nafion solution. After agitating the solutions at room temperature for $3 \mathrm{~h}$ using a vortex, the mixture was incubated for three days at $4{ }^{\circ} \mathrm{C}$.

For construction of the anode, $48 \mathrm{U}$ of FADGDH per $\mathrm{cm}^{2}$ of carbon cloth electrode was employed. $40 \mu \mathrm{L}$ of FADGDH solution $(1.2 \mathrm{U} / \mu \mathrm{L})$ was mixed with $10 \mu \mathrm{L}$ of carbon ink solution and $10 \mu \mathrm{L}$ of $100 \mathrm{mM}$ potassium phosphate buffer (PPB) $(\mathrm{pH} 7.0)$. The mixture $(50 \mu \mathrm{L})$ was homogeneously deposited onto $1 \mathrm{~cm}^{2}$ of carbon cloth and air-dried at $4^{\circ} \mathrm{C}$ for $3 \mathrm{~h}$ to allow the mixture to coat the carbon cloth. The carbon cloth electrode was immersed in $1 \%(\mathrm{w} / \mathrm{v})$ glutaraldehyde solution for $30 \mathrm{~min}$. and then washed with $10 \mathrm{mM}$ of Tris$\mathrm{HCl}$ buffer ( $\mathrm{pH}$ 7.0). The anode electrode was stored in 100 $\mathrm{mM}$ PPB (pH 7.0) at $4^{\circ} \mathrm{C}$ until use.

For construction of the cathode, $\mathrm{Pt} / \mathrm{C}$ was used as a cathode catalyst. The mixture of Pt/C ink $(10 \mu \mathrm{L})$ and $100 \mathrm{mM}$ PPB ( $\mathrm{pH} 7.0)(50 \mu \mathrm{L})$ was homogeneously deposited onto 1 $\mathrm{cm}^{2}$ of carbon cloth and air-dried at $4^{\circ} \mathrm{C}$ for $3 \mathrm{~h}$. Then, $50 \mu \mathrm{L}$ of $3.0 \%(\mathrm{w} / \mathrm{v})$ PDMS was homogeneously deposited on the carbon cloth.

The anode and the cathode electrodes were attached to a 10-ml water-jacket cell (model VC-2; Bioanalytical Systems, West Lafayette, IN). In the enzyme fuel cell, $100 \mathrm{mM}$ PPB ( $\mathrm{pH}$ 7.0) was stirred at $250 \mathrm{rpm}$ with a magnetic stirrer at $25^{\circ} \mathrm{C}$. The voltage and current generated by the cell between the two electrodes were measured by applying an external variable load resistance (model 278620; Yokogawa Electric Corporation, Tokyo, Japan) and using a digital multimeter (R6441C; Advantest, Tokyo, Japan) for the voltage and current measurements, with $20 \mathrm{mM}$ glucose at the anode. The dependence of the power on the glucose concentration was investigated by adding various concentrations of glucose at an optimal load and a temperature of $25^{\circ} \mathrm{C}$.

\subsection{Enzyme Fuel Cell Construction for Power Generation Based on Cellulolytic Sugars}

For the anode preparation, $45 \mathrm{U}$ of FADGDH was immobilized on carbon cloth $(2 \times 3 \mathrm{~cm})$ together with carbon ink. Other procedures were the same as described above. For the cathode preparation, bilirubin oxidase (BOD) was employed as the cathode catalyst instead of Pt/C. 3.6 U BOD was immobilized on the carbon cloth electrode $(2 \times 3 \mathrm{~cm})$ using the same preparation method as for the anode. For evaluation of the biofuel cell, each of the anode and cathode electrode was placed in a $10-\mathrm{mL}$ water jacket cell (model VC-2; BAS, Inc.), and the cell was exposed to the open air. In the enzyme fuel cell, $100 \mathrm{mM}$ PPB (pH 7.0) was stirred at $250 \mathrm{rpm}$ with a magnetic stirrer at $37^{\circ} \mathrm{C}$, and cellulolytic sugars such as cellobiose, cellotriose or cellotetraose were added to give the final concentration of $2 \mathrm{mM}$.

The voltage and current generated by the carbon cloth were measured by applying an external variable load resistance (Model 278620, Yokogawa Electric Corporation, Tokyo, Japan) and using a digital multimeter (Advantest, Tokyo, Japan).

\section{RESULT AND DISCUSSION}

\section{1. Construction of Multi-Module Enzyme Fuel Cell}

We first constructed a single-module enzyme fuel cell, employing FADGDH as the anode catalyst directly immobilized on the carbon cloth $\left(1 \mathrm{~cm}^{2}\right)$.

Fig. (1) shows the current-voltage behavior of the thus constructed enzyme fuel cell using $20 \mathrm{mM}$ of glucose as the substrate (fuel) at $37^{\circ} \mathrm{C}$. The highest power generation, 3.5 $\mu \mathrm{W}$, was achieved at $10 \mathrm{k} \Omega$. A short-circuit current of 54.3 $\mu \mathrm{A}$ and an open-circuit voltage of $0.35 \mathrm{~V}$ were also observed.

By employing $10 \mathrm{k} \Omega$ as the resistance, the operational stability of this enzyme fuel cell was investigated at $25^{\circ} \mathrm{C}$ with $20 \mathrm{mM}$ of glucose Fig. (2). 

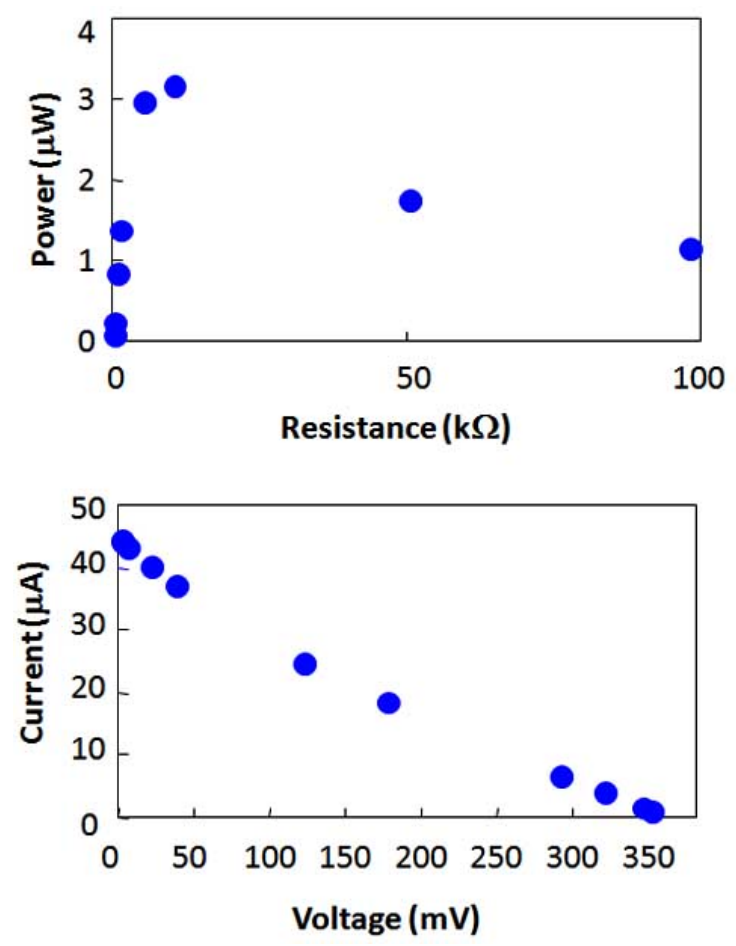

Fig. (1). Current voltage behavior of carbon cloth based FADGDH enzyme fuel cell.

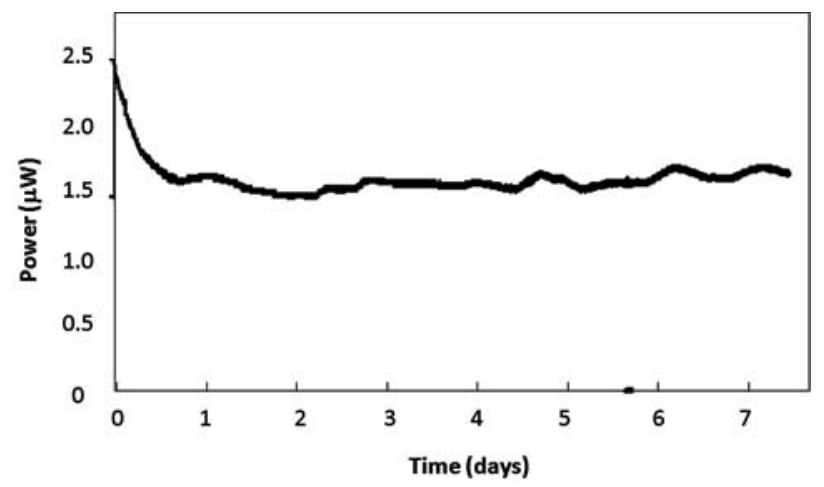

Fig. (2). Operational stability of enzyme fuel cell employing FADGDH (Anode: carbon cloth electrode employing FADGDH complex; Cathode: carbon cloth electrode employing platinized carbon; Reaction buffer: $100 \mathrm{mM}$ PPB (pH 7.0) containing $20 \mathrm{mM}$ glucose).

Within 12 hours of operation, a rapid decay in power generation was observed. This decrease might be due to enzymes peeling off the carbon cloth. After 20 hours of operation, constant power generation was observed $(\sim 1.5 \mu \mathrm{W})$ and continued for more than 7 days.

We then constructed a multi-module enzyme fuel cell based on the direct electron transfer principle employing FADGDH as the anode catalyst and $\mathrm{Pt} / \mathrm{C}$ as the cathode catalyst.

Fig. (3) shows a schematic diagram of the multi-module enzyme fuel cell. Each module is composed of one reaction vessel $(10 \mathrm{~mL})$ with FADGDH immobilized carbon cloth anode $\left(2 \mathrm{~cm}^{2}\right)$ and $\mathrm{Pt} / \mathrm{C}$ immobilized carbon cloth cathode (2 $\mathrm{cm}^{2}$ ). By connecting each module in series or in parallel, up to $3 \times 3$ modules $\left(18 \mathrm{~cm}^{2}\right)$ can be operated simultaneously.

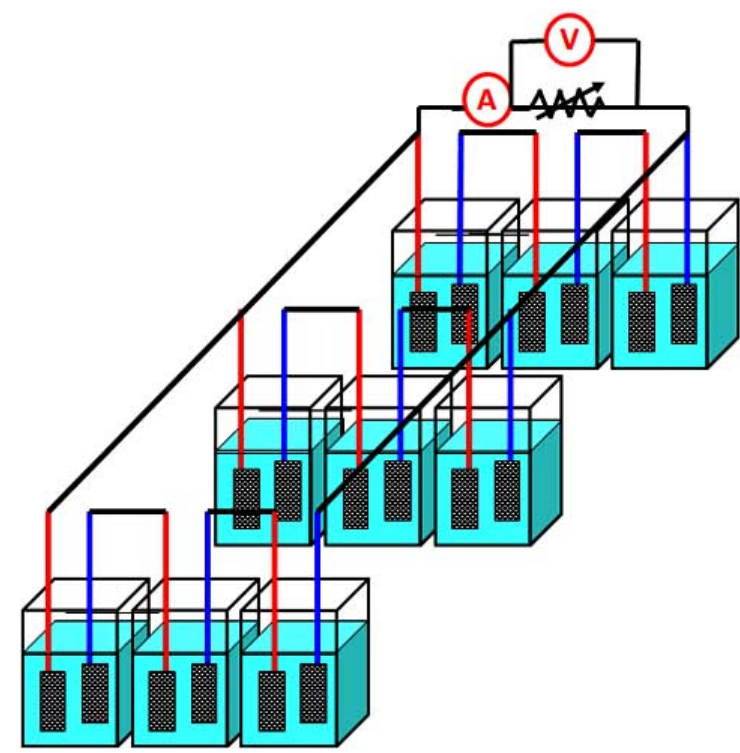

Fig. (3). Schematic diagram of direct electron transfer type enzyme fuel cell with multi (9) cellular modules (Anode: carbon cloth electrode employing FADGDH complex $\left(2 \mathrm{~cm}^{2}\right)$; Cathode: carbon cloth electrode employing platinized carbon $\left(2 \mathrm{~cm}^{2}\right)$; Reaction buffer: 100 $\mathrm{mM}$ PPB (pH 7.0) containing $20 \mathrm{mM}$ glucose).
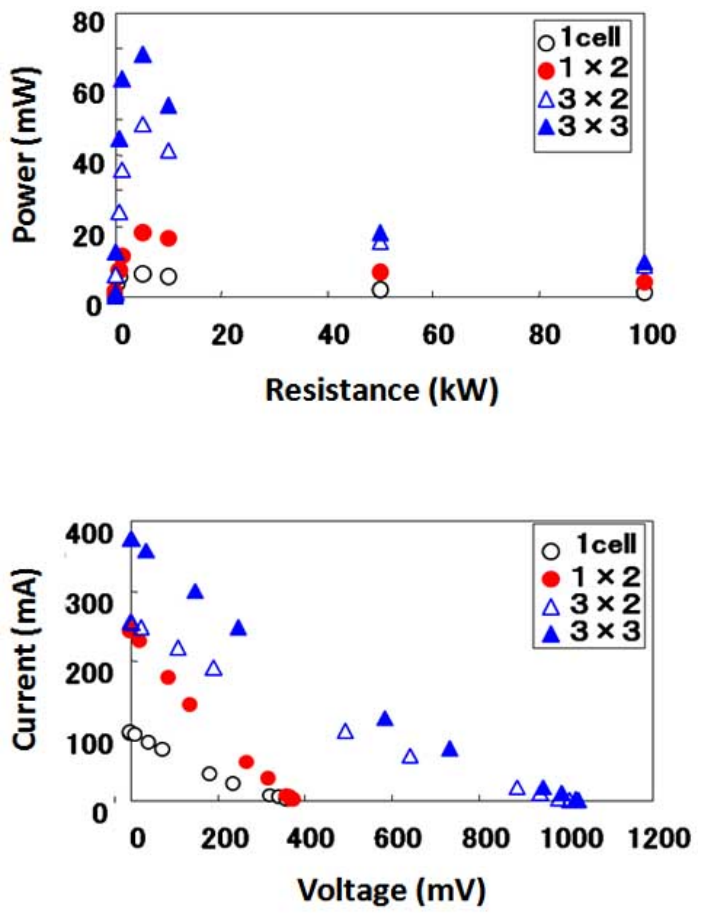

Fig. (4). Power generation from direct electron transfer type enzyme fuel cell with multi cellular modules

Fig. (4) shows the power generated by enzyme fuel cells with $1,1 \times 2\left(4 \mathrm{~cm}^{2}\right), 3 \times 2\left(12 \mathrm{~cm}^{2}\right)$ and $3 \times 3\left(18 \mathrm{~cm}^{2}\right)$ modules. As the surface area of the anode was double that shown in Fig. (2), the observed current $(95.6 \mu \mathrm{A})$ and power $(6.6 \mu \mathrm{W}$, $\left.3.3 \mu \mathrm{W} / \mathrm{cm}^{2}\right)$ were also double those of the one-module cell employing a $1 \mathrm{~cm}^{2}$ anode, whereas the open-circuit voltage was almost the same $(0.37 \mathrm{~V})$. In the enzyme fuel cell with $1 \times 2$ modules, in which two modules were connected in parallel, the current and power were doubled (242 $\mu \mathrm{A}, 14.5$ 

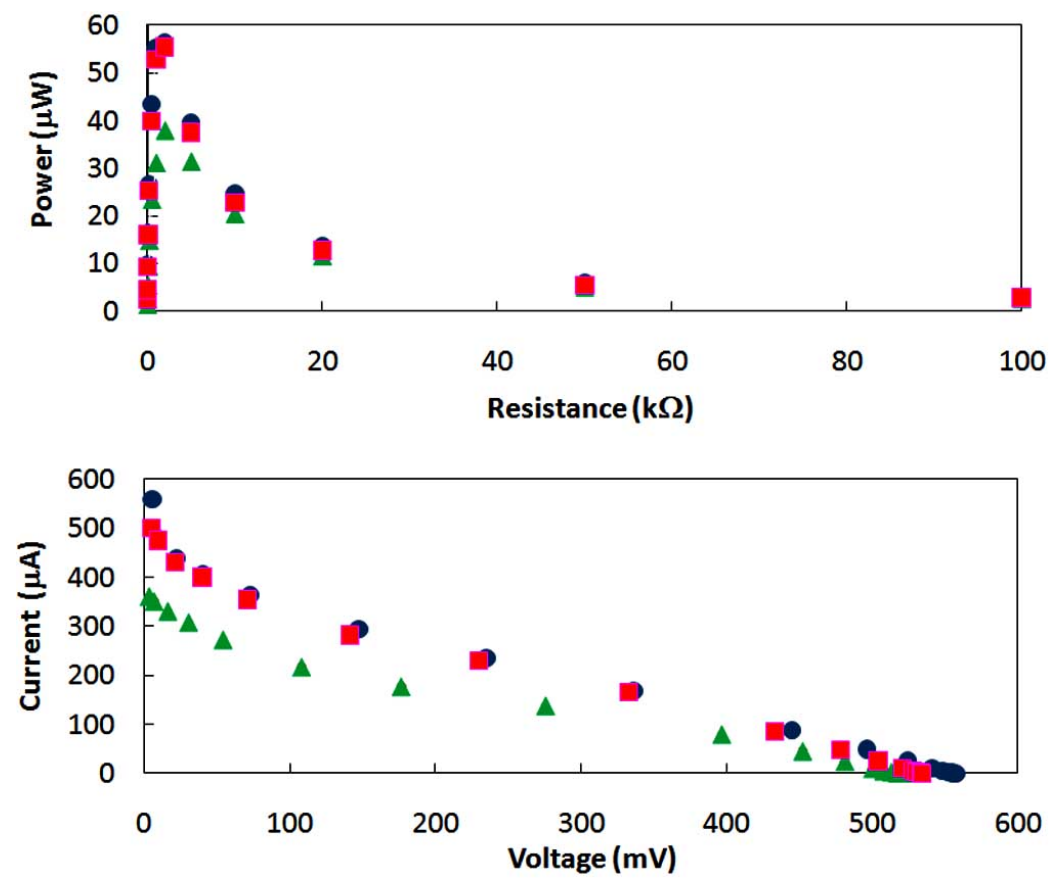

Fig. (5). Power generation from cellulolytic sugars using direct electron transfer type enzyme fuel cell employing FADGDH

$\mu \mathrm{W})$, whereas the open-circuit voltage was the same $(0.37 \mathrm{~V})$. Similarly, by connecting three modules in series, the open-circuit voltage increased 3 -fold. Finally, the $3 \times 3$ module enzyme fuel cell generated $68 \mu \mathrm{W}\left(3.8 \mu \mathrm{W} / \mathrm{cm}^{2}\right)$, which was almost 9 times that of the single-module enzyme fuel cell, as expected.

These results demonstrated that carbon cloth is a feasible electrode material for the direct electron transfer type enzyme fuel cell, not only for its potential cost efficiency, material flexibility and stability, but also its scalability.

\section{2. Power Generation Based on Cellulolytic Sugars}

In order to investigate the feasibility of cellulolytic sugars as the substrate for FADGDH in direct electron transfer type enzyme fuel cells, we operated the fuel cell using either $2 \mathrm{mM}$ cellobiose, cellotriose or cellotetraose. For this investigation, a carbon cloth cathode with BOD as the cathodic catalyst was employed instead of $\mathrm{Pt} / \mathrm{C}$.

Fig. (5) shows the power generation from cellulolytic sugars for varying resistance. The maximum power was observed at the resistance of $500 \Omega$ : cellobiose $56 \mu \mathrm{W}(9.3$ $\left.\mu \mathrm{W} / \mathrm{cm}^{2}\right)$, cellotriose $55 \mu \mathrm{W}\left(9.2 \mu \mathrm{W} / \mathrm{cm}^{2}\right)$, and cellotetraose $38 \mu \mathrm{W}\left(6.3 \mu \mathrm{W} / \mathrm{cm}^{2}\right)$.

Although the electric power generation demonstrated in this study was lower than those reported by several authors, such as by Zebda et al. [18, 19], our results clearly demonstrated that enzyme fuel cells employing FADGDH are capable of generating electric power utilizing variety of cellulolytic sugars as the substrate, including glucose. Thanks to the direct electron transfer capability of the enzyme, simple structure and component of enzyme electrode was achieved, consequently allowed to utilize cost effective and versatile carbon cloth as the electrode materials. Together with the currently developing variety of enzyme immobilization method/materials and also the advanced microfulidics engi- neering, the combination of FADGDH and carbon cloth will realize the effective and practical electrochemical utilization of biomass.

\section{CONCLUSIONS}

An enzyme fuel cell employing a carbon cloth electrode and bacterial FADGDH based on the direct electron transfer principle was constructed. The enzyme fuel cell was stable for more than 7 days of continuous operation. The $3 \times 3$ module $\left(18 \mathrm{~cm}^{2}\right)$ enzyme fuel cell generated $68 \mu \mathrm{W}(3.8$ $\mu \mathrm{W} / \mathrm{cm}^{2}$ ) using glucose as the substrate, which was almost 9 times that of a single-module enzyme fuel cell. Cellulolytic sugars were revealed to be a good substrate for the enzyme fuel cell. Together with the feasibility of carbon cloth as the electrode material, the application of FADGDH as the anode catalyst will enable electrochemical utilization of biomass.

\section{REFERENCES}

[1] Bullen, R.A.; Arnot, T.C.; Lakeman, J.B.; Walsh, F.C. Biofuel cells and their development. Biosens. Bioelectron., 2006, 21, 2015-45.

[2] Ivnitski, D.; Artyushkova, K.; Rincon, R.A.; Atanassov, P.; Luckarift, H.R.; Johnson, G.R. Entrapment of enzymes and carbon nanotubes in biologically synthesized silica: glucose oxidasecatalyzed direct electron transfer. Small, 2008, 4, 357-64.

[3] Cameron, M.D.; Aust, S.D. Cellobiose dehydrogenase - an extracellular fungal flavocytochrome. Enzyme Microb. Tech., 2001, 28(2-3), 129-38.

[4] Halberg, B.M.; Henriksson, G.; Pettersson, G.; Divne, C. Crystal structure of the flavoprotein domain of the extracellular flavocytochrome cellobiose dehydrogenase. J. Mol. Biol., 2002, 315, 42134.

[5] Tasca, F.; Gorton, L.; Herreither, W.; Haltrich, D.; Ludwig, R.; Noll, G. Direct electron transfer at cellobiose dehydrogenase modified anodes for biofuel cells. J. Phys. Chem., 2008, 112, 995661.

[6] Tasca, F.; Gorton, L.; Harreither, W.; Haltrich, D.; Ludwig, R.; Noll, G. Comparison of direct and mediated electron transfer for cellobiose dehydrogenase from Phanerochaete sordida. Anal. Chem., 2009, 81, 2791-8. 
[7] Desriani; Ferri, S.; Sode, K. Functional expression of Phanerochaete chrysosporium cellobiose dehydrogenase flavin domain in Escherichia coli. Biotechnol. Lett., 2010, 32, 855-859.

[8] Kakehi, N.; Yamazaki, T.; Tsugawa, W.; Sode, K. A novel wireless glucose sensor employing direct electron transfer principle based enzyme fuel cell. Biosens. Bioelectron., 2007, 22, 2250-55.

[9] Okuda-Shimazaki, J.; Kakehi, N.; Yamazaki, T.; Tomiyama, M.; Sode, K. Biofuel cell system employing thermostable glucose dehydrogenase. Biotechnol. Lett., 2008, 30,1753-8.

[10] Inose, K.; Fujikawa, M.; Yamazaki, T.; Kojima, K.; Sode, K. Cloning and expression of the gene encoding catalytic subunit of thermostable glucose dehydrogenase from Burkholderia cepacia in Escherichia coli. Biochim. Biophys. Acta, 2003, 1645, 133-8.

[11] Nakazawa, Y.; Yamazaki, T.; Tsugawa, W.; Ikebukuro, K.; Sode, K. Amperometric glucose sensor using thermostable co-factor binding glucose dehydrogenase. IEEJ Trans. Sens. Macromachin., 2003, 123, 185-9.

[12] Sode, K.; Tsugawa, W.; Yamazaki, T.; Watanabe, M.; Ogasawara, N.; Tanaka, M. A novel thermostable glucose dehydrogenase varying temperature properties by altering its quaternary structures. Enzyme Microbial. Tech., 1996, 19, 82-5.

[13] Tsuya, T.; Ferri, S.; Fujikawa, M.; Yamaoka, H.; Sode, K. Cloning and functional expression of glucose dehydrogenase complex of
Burkholderia cepacia in Escherichia coli. J. Biotechnol., 2006, 123, 127-36.

[14] Yamaoka, H.; Ferri, S.; Fujikawa, M.; Sode, K. Essential role of the small subunit of thermostable glucose dehydrogenase from Burkholderia cepacia. Biotechnol. Lett., 2004, 26, 1757-61.

[15] Yamazaki, T.; Tsugawa, W.; Sode, K. Subunit analyses of a novel thermostable glucose dehydrogenase showing different temperature properties according to its quaternary structure. Appl. Biochem. Biotech., 1999, 77-9, 325-35.

[16] Yamazaki, T.; Tsugawa, W.; Sode, K. Increased thermal stability of glucose dehydrogenase by cross-linking chemical modification. Biotechnol. Lett., 1999, 21, 199-202.

[17] Hanashi, T.; Yamazaki, T.; Tsugawa, W.; et al. Biocapacitor-A novel category of biosensor. Biosens. Bioelectron., 2009, 24, 1837 42.

[18] Zebda, A.; Renaud, L.; Cretin, M.; et al. A microfluidic glucose biofuel cell to generate micropower from enzymes at ambient temperature. Electrochem. Commun., 2009, 11, 592-5.

[19] Zebda, A.; Renaud, L.; Cretin, M.; et al. Electrochemical performance of a glucose/oxygen microfluidic biofuel cell. J. Power. Source., 2009, 193, 602-6.

(C) Desriani et al.; Licensee Bentham Open.

This is an open access article licensed under the terms of the Creative Commons Attribution Non-Commercial License (http://creativecommons.org/licenses/by-nc/3.0/) which permits unrestricted, non-commercial use, distribution and reproduction in any medium, provided the work is properly cited. 